\title{
Cretaceous Stratigraphy of Pakistan
}

\author{
Muhammad Sadiq Malkani \\ Geological Survey of Pakistan, Muzaffarabad, Azad Kashmir, Pakistan \\ Email: malkanims@yahoo.com
}

How to cite this paper: Malkani, M.S. (2019) Cretaceous Stratigraphy of Pakistan. Open Journal of Geology, 9, 671-673. https://doi.org/10.4236/ojg.2019.910071

Received: August 17, 2019

Accepted: September 21, 2019

Published: September 24, 2019

Copyright $\odot 2019$ by author(s) and Scientific Research Publishing Inc. This work is licensed under the Creative Commons Attribution International License (CC BY 4.0).

http://creativecommons.org/licenses/by/4.0/

\begin{abstract}
Cretaceous strata of Pakistan yielded many significant fossils of terrestrial ecosystems like poripuch (all caudals are procoelous) lithostrotian titanosaurian sauropods, abelisauroids theropods, mesoeucrocodiles, pterosaurs and gymnosperm stem wood. Both marine and non-marine strata well exposed through the Cretaceous, Jurassic-Cretaceous and Cretaceous-Paleogene boundaries found in Pakistan especially in Indus Basin. Indus Basin represents strata from Precambrian to Recent. Here a glimpse of Cretaceous Stratigraphy of Pakistan is being presented.
\end{abstract}

\section{Keywords}

Terrestrial, Marine, Stratigraphy, Cretaceous, Pakistan

\section{Introduction}

Pakistan is lucky to host the Gondwanan, Eurasian and Tethyan heritage. Gondwanan heritage is represented by Indus Basin of Pakistan located in the centre, south and eastern Pakistan. The Eurasian heritage is represented by Hindukush-Karakoran basin located in northernmost Pakistan. The Tethyan heritage is represented by Balochistan magmatic arc and basin in western Pakistan, and Kohistan-Ladakh magmatic arc located in northern Pakistan. Cretaceous rocks are exposed in all these basins but only Indus basin yields Cretaceous fauna [1] so far. So here Cretaceous Stratigraphy of Indus basin is being presented.

\section{Cretaceous Stratigraphy of Indus Basin of Pakistan}

Cretaceous deposits (Figure 1) are more than 3000 meters thick in the Indus basin. The Cretaceous of upper Indus (Kohat-Potwar) Basin shows marine Chichali, (glauconitic muds), marginal marine Lumshiwal (quartzose sandstone with subordinate shale) and Kawagarh (limestone) and terrestrial to deltaic Indus (coal, laterite, carbonaceous shale $=$ Vitakri Lameta sediments) formations 


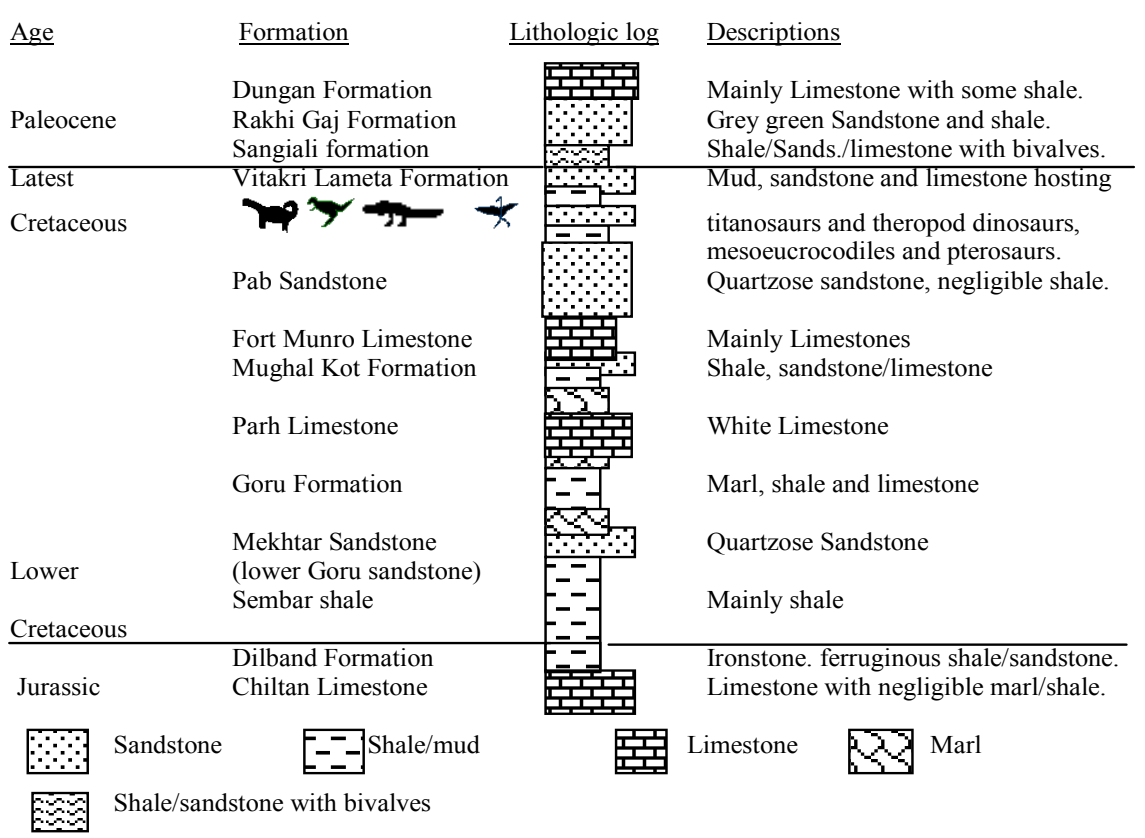

Figure 1. Cretaceous stratigraphic sequence of Indus basin of Pakistan.

followed by the Lower Paleocene deltaic Hangu Formation (coal, sandstone and shale). Middle Indus (Sulaiman) and lower Indus (Kirthar) basins represent the Lower Cretaceous fine pelagic, shallow marine and deltaic Parh Group (Sembar, Goru, Parh formations; belemnite bearing shale, marl and limestone), and the Upper Cretaceous was emerged by a regression of sea which shows the Mughal Kot (shale and sandstone with minor limestone), Fort Munro (limestone), Pab (mainly sandstone with negligible shale) and Vitakri Lameta (terrestrial alternating red muds and sandstone, at places limestone) formations of Fort Munro Group, deposited under muddy to sandy shelf, distal deltaic and fluviatile environments. At early Paleocene the transgression of sea emerged, which deposited the marine Sangiali (bivalves, nautiloids and gastropods bearing limestone and shale with some Deccan volcanic dust), Rakhi Gaj (sandstone and shale with Deccan volcanic dust observed in Rakhi Gaj section of Dera Ghazi Khan, central Pakistan) and Dungan Limestone of Sangiali Group. Eocene was mostly marine, deltaic and partly terrestrial. In the Oligocene and onward the mollase alluvial environments became dominant.

The contact of the Cretaceous Sembar shale and marl with the Jurassic Dilband Formation (disconformity) and or Chiltan limestone represents the Jurassic-Cretaceous J/K boundary which consists of light brown to grey shale and marl in the central and southern Kirthar basin, while the red iron stone beds (Dilband iron deposits) in the northern Kirthar basin. Further the poorly preserved and poorly recognized fossils of Brohisaurus kirthari were also found from the northern Kirthar basin. The contact of Cretaceous Sembar shale and marl with the Jurassic Loralai limestone in the Sulaiman basin, and the contact of Chichali glauconitic shale and sandstone with the Jurassic Samanasuk limestone and shale in the upper Indus (Kohat and Potwar) basin represent the Juras- 
sic Cretaceous J/K boundary which consists of light brown to grey shale/marl.

The Cretaceous-Paleogene K-Pg boundary sharing formations in the Lower Indus (Kirthar) and Middle Indus (Sulaiman) basins are the latest Cretaceous Vitakri Lameta Formation (two red, maroon, grey green clay horizons alternated with two sandstone horizons, limestone at places) and Early Paleocene Khadro and Bara formations (Lower Indus) and Sangiali and Rakhi Gaj formations (Middle Indus). The Vitakri Lameta Formation belongs to only upper part (up to $35 \mathrm{~m}$ thick) of Previous Pab Formation (up to $800 \mathrm{~m}$ thick) in Indus Basin. In Western Sulaiman Basin, the K/T boundary is represented by Ziarat laterite of Vitakri Formation which is contacted by Cretaceous Parh limestone (porcelaneous belemnite bearing) and Paleocene Dungan limestone (autoclstic marine invertebrates bearing). The K/T boundary in Upper Indus are Cretaceous Chichali (ammonite bearing glauconitic shale and sandstone), or Lumshiwal (quartzose sanstone) or Kawagarh (NW of Upper Indus; limestones) and Latest Cretaceous Indus Formation (laterite, carbonaceous shale; = Vitakri Lameta Formation; lower Hangu). At places the K/T boundary is represented as infra tertiary boundary between the varying Tertiary rocks with also varying older rocks such as Precambrian, Paleozoic and Mesozoic units.

Until now the latest Cretaceous dinosaurs (and other archosaurs) from Sulaiman basin are reported from the Vitakri Lameta Formation [1], which represents fluvial meandering river and over bank system. The K/T boundary is marked on the top of fluvial sandstone (white, thin to thick bedded, slightly calcareous to non calcareous, poorly sorted and have ferruginous nodules and rusty brown weathering on bivalve fossils) unit of Vitakri Lameta Formation which is capped by the shallow marine bivalves bearing green shale, sandstone and yellow brown limestone of Early Paleocene Sangiali Formation. The Vitakri Lameta Formation thickness varying from 15 to $35 \mathrm{~m}$ is increasing toward WSW and decreasing ENE directions.

The $\mathrm{J} / \mathrm{K}$ and $\mathrm{K} / \mathrm{T}$ boundaries in Pakistan represent wide exposures of marine as well as continental condition. Indus Basin of Pakistan holds a large number of section sites for lateral and vertical rapid environmental/climate change in the Cretaceous greenhouse world.

\section{Acknowledgements}

This work is a contribution to UNESCO/IUGS/IGCP 679 project.

\section{Conflicts of Interest}

The author declares no conflicts of interest regarding the publication of this paper.

\section{References}

[1] Malkani, M.S. (2006) Lithofacies and Lateral Extension of Latest Cretaceous Dinosaur Beds from Sulaiman Foldbelt, Pakistan. Sindh University Research Journal (Science Series), 38, 1-32. 